\title{
BLOOD CHANGES INDUCED BY VENESECTION IN WOMEN WITH TOXEMIA OF LATE PREGNANCY
}

\author{
By FRED W. OBERST AND E. D. PLASS \\ (From the Department of Obstetrics and Gynecology, State University of Iowa, Iowa City).
}

(Received for publication January 19, 1940)

The beneficial effect of blood letting in the toxemias of late pregnancy is well recognized, but little or no accurate information is available concerning the method of its action. During the course of investigations on the water concentration and the acid-base balance in a series of patients with various clinical types of toxemia (1), certain observations were made at different times in the same individual in the hope of determining the physico-chemical effects of venesection. The methods employed were those previously described $(2,3)$, except that the $\mathrm{pH}$ was determined colorimetrically and corrected to the electrometric value by subtracting a determined factor, 0.34 . In each case the $\mathrm{pH}$ of the two samples (the first and last portions of the venesection) was compared with the same standard and then one was compared with the other. The clinical data on the patients mentioned are available in Tables I, II, and III of the communication mentioned above (1).

Venesection was introduced into the therapy of the toxemias on an empirical basis in the belief that it would remove from the body some of the hypothetical "toxin" supposedly responsible for the condition. More recently, there has been a tendency to view its action as largely physical in nature. It is known that toxemic women with well defined clinical edema usually respond to therapy which invokes the mobilization of tissue water. The removal of large volumes (300 to $600 \mathrm{cc}$.) of blood increases the water content of the plasma and decreases the cell volume of the whole blood by drawing tissue water into the blood stream. This sequence of events is evidently based upon two physiologic facts: (1) the volume of circulating blood tends to remain constant, and (2) deficiencies in its volume are made up promptly by the withdrawal of tissue fluid when other external sources are unavailable. The fluid which is thus brought into the blood stream can then be eliminated by the kidneys, with the estab- lishment of a mild diuresis. In all probability it is the extracellular tissue fluid which is first mobilized for this purpose.

Assuming the correctness of these observations, it would then appear that study of the first and last portions of a slowly performed venesection might give some indication of the composition of the tissue fluids.

One normal male control (a professional blood donor) and six toxemic patients (one hypertensive, three non-convulsive toxemics, and two eclamptics) were studied in this fashion, the amount of blood taken varying from 275 to 600 cc. and the time of withdrawal from 10 to 15 minutes. In certain instances a third specimen

TABLE I

Data on the details of the renesections

\begin{tabular}{|c|c|c|c|c|}
\hline$\underset{\text { Case }}{\text { Cam- }}$ & $\begin{array}{c}\text { Hos- } \\
\text { pital } \\
\text { number }\end{array}$ & $\begin{array}{l}\text { Amount } \\
\text { of blood } \\
\text { drawn }\end{array}$ & $\begin{array}{l}\text { Time } \\
\text { of a } \\
\text { vene- } \\
\text { sec- } \\
\text { tion }\end{array}$ & Remarks \\
\hline $\begin{array}{r}94 a \\
b\end{array}$ & & 600 & $\begin{array}{c}\text { min- } \\
\text { utes } \\
15\end{array}$ & Professional male donor \\
\hline $\begin{array}{r}89 a \\
b\end{array}$ & D 5247 & 400 & 15 & Toxemia without convulsions \\
\hline $\begin{array}{r}90 \mathrm{a} \\
\mathrm{b}\end{array}$ & H 13800 & 450 & 10 & Toxemia without convulsions \\
\hline $\begin{array}{r}91 \mathrm{a} \\
\mathrm{b}\end{array}$ & J 1409 & 300 & 15 & $\begin{array}{l}\text { Chronic cardiovascular renal } \\
\text { disease }\end{array}$ \\
\hline $\begin{array}{r}92 a \\
b\end{array}$ & J 5215 & 275 & 15 & $\begin{array}{l}\text { Postpartum eclampsia; the } \\
\text { blood was drawn } 4 \text { or } 5 \text { hours } \\
\text { after the last seizure }\end{array}$ \\
\hline $\begin{array}{r}93 \mathbf{a} \\
\mathbf{b} \\
\mathbf{c}\end{array}$ & J 5370 & $\begin{array}{r}400 \\
50\end{array}$ & 15 & $\begin{array}{l}\text { Eclampsia; blood drawing was } \\
\text { made } 1 \frac{1}{2} \text { hours after the last } \\
\text { seizure. The third specimen } \\
\text { (c) was drawn } 15 \text { minutes } \\
\text { after the venesection was } \\
\text { ended }\end{array}$ \\
\hline $\begin{array}{r}95 \mathbf{a} \\
\mathbf{b} \\
\mathbf{c}\end{array}$ & J 6209 & $\begin{array}{r}450 \\
50\end{array}$ & 10 & $\begin{array}{l}\text { Toxemia without convuls ions. } \\
\text { The third specimen (c) was } \\
\text { drawn } 3 \text { hours later, shortly } \\
\text { after glucose and morphine } \\
\text { had been given }\end{array}$ \\
\hline
\end{tabular}


TABLE II

Water distribution in the first (a) and the last $(b),(c)$, portions of a venesection

\begin{tabular}{|c|c|c|c|c|c|c|c|c|c|c|}
\hline \multirow[b]{2}{*}{$\underset{\text { ber }}{\text { Case }}$} & \multirow[b]{2}{*}{$\begin{array}{l}\text { Cell } \\
\text { vol- } \\
\text { ume }\end{array}$} & \multicolumn{3}{|c|}{ Bpecifio gravity } & \multicolumn{3}{|c|}{ Water } & \multicolumn{3}{|c|}{ Hemogdobin } \\
\hline & & Plasms & $\begin{array}{l}\text { Whole } \\
\text { blood }\end{array}$ & Cells & 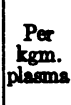 & $\begin{array}{l}\text { Per } \\
\text { tom. } \\
\text { whole } \\
\text { blood }\end{array}$ & $\begin{array}{c}\text { Pex } \\
\text { kgm. } \\
\text { cells }\end{array}$ & $\begin{array}{c}\text { Per } \\
100 \text { oc. } \\
\text { whole } \\
\text { blood }\end{array}$ & $\underset{\text { cem. }}{\text { Per }}$ & $\underset{\substack{\text { kem } \\
\text { water }}}{\text { wer }}$ \\
\hline & $\begin{array}{l}\text { per } \\
\text { cent }\end{array}$ & & & & grams & grams & grams & m. q. & m. $\boldsymbol{\alpha .}$ & m. ๓q. \\
\hline $94 \mathrm{ag}$ & $\begin{array}{l}48.0 \\
46.0\end{array}$ & \begin{tabular}{|l|}
1.0181 \\
1.0169
\end{tabular} & $\begin{array}{l}1.0477 \\
1.0425\end{array}$ & $\begin{array}{l}1.081 \\
1.073\end{array}$ & $\begin{array}{l}912 \\
916\end{array}$ & $\begin{array}{l}792 \\
797\end{array}$ & $\begin{array}{l}665 \\
663\end{array}$ & \begin{tabular}{|r|}
10.12 \\
9.68
\end{tabular} & $\begin{array}{l}19.50 \\
19.04\end{array}$ & $\begin{array}{l}29.35 \\
29.50\end{array}$ \\
\hline $\begin{array}{r}89 \mathrm{a} \\
\mathrm{b}\end{array}$ & $\begin{array}{l}42.0 \\
38.0\end{array}$ & \begin{tabular}{|l|}
1.0192 \\
1.0160
\end{tabular} & $\begin{array}{l}1.0446 \\
1.0416\end{array}$ & $\begin{array}{l}1.080 \\
1.079\end{array}$ & $\begin{array}{l}914 \\
926\end{array}$ & $\begin{array}{l}801 \\
803\end{array}$ & $\begin{array}{l}655 \\
645\end{array}$ & $\begin{array}{l}8.82 \\
8.47\end{array}$ & $\begin{array}{l}19.42 \\
20.65\end{array}$ & $\begin{array}{l}29.70 \\
32.05\end{array}$ \\
\hline $\begin{array}{r}90 \mathrm{a} \\
\mathrm{b}\end{array}$ & $\begin{array}{l}27.5 \\
24.0\end{array}$ & $\begin{array}{l}1.0184 \\
1.0169\end{array}$ & $\begin{array}{l}1.0366 \\
1.0356\end{array}$ & $\begin{array}{l}1.086 \\
1.088\end{array}$ & $\begin{array}{l}910 \\
916\end{array}$ & $\begin{array}{l}855 \\
858\end{array}$ & $\begin{array}{l}713 \\
695\end{array}$ & $\begin{array}{l}4.13 \\
4.03\end{array}$ & $\begin{array}{l}14.22 \\
15.46\end{array}$ & $\begin{array}{l}20.00 \\
22.25\end{array}$ \\
\hline$\underset{b}{918}$ & $\begin{array}{l}42.7 \\
41.0\end{array}$ & $\begin{array}{l}1.0126 \\
1.0140\end{array}$ & $\begin{array}{l}1.0427 \\
1.0413\end{array}$ & $\begin{array}{l}1.080 \\
.1 .080\end{array}$ & $\begin{array}{l}918 \\
921\end{array}$ & $\begin{array}{l}798 \\
804\end{array}$ & $\begin{array}{l}648 \\
646\end{array}$ & $\begin{array}{r}9.50 \\
10.13\end{array}$ & $\begin{array}{l}20.60 \\
22.90\end{array}$ & $\begin{array}{l}31.75 \\
35.40\end{array}$ \\
\hline $\begin{array}{r}92 \mathrm{a} \\
\mathrm{b}\end{array}$ & $\begin{array}{l}31.5 \\
30.5\end{array}$ & $\begin{array}{l}1.0170 \\
1.0163\end{array}$ & $\begin{array}{l}1.0377 \\
1.0365\end{array}$ & $\begin{array}{l}1.085 \\
1.082\end{array}$ & $\begin{array}{l}916 \\
918\end{array}$ & $\begin{array}{l}835 \\
838\end{array}$ & $\begin{array}{l}666 \\
666\end{array}$ & $\begin{array}{l}6.38 \\
6.25\end{array}$ & $\begin{array}{l}18.65 \\
18.92\end{array}$ & $\begin{array}{l}28.00 \\
28.41\end{array}$ \\
\hline 93 & 41.0 & 1.0160 & 1.0459 & 1.090 & 918 & 801 & 645 & 9.88 & 19.85 & 30.80 \\
\hline & 40.2 & 1.0157 & 1.0440 & 1.085 & 919 & 806 & 653 & 9.06 & 20.76 & 31.80 \\
\hline $\begin{array}{r}95 \mathrm{a} \\
\mathrm{b} \\
\mathrm{c}\end{array}$ & $\begin{array}{l}46.0 \\
43.0 \\
42.5\end{array}$ & $\begin{array}{l}1.0121 \\
1.0105 \\
1.0095\end{array}$ & $\begin{array}{l}1.0459 \\
1.0438 \\
1.0395\end{array}$ & $\begin{array}{l}1.088 \\
1.089 \\
1.079\end{array}$ & $\begin{array}{l}908 \\
912 \\
914\end{array}$ & $\begin{array}{l}783 \\
791 \\
792\end{array}$ & $\begin{array}{l}641 \\
639 \\
635\end{array}$ & \begin{tabular}{|r|}
10.12 \\
9.51 \\
8.75
\end{tabular} & $\begin{array}{l}20.21 \\
20.30 \\
19.10\end{array}$ & $\begin{array}{l}31.55 \\
31.75 \\
30.05\end{array}$ \\
\hline
\end{tabular}

was removed 15 minutes after the second. The data on the details of the venesection and the time of collection of the samples are recorded in Table I.
The water distribution in the various specimens is presented in Table II.

In the normal male subject it is apparent that after the venesection the cell volume and the various specific gravities are reduced; the water content of the plasma and whole blood is increased, while that of the red cells is practically unchanged; and the hemoglobin of the whole blood is appreciably reduced. It should be noted that the hemoglobin per $\mathrm{kgm}$. of cells and of water is not altered.

In general, the results in the toxic women are of the same order and magnitude except that the hemoglobin concentrations per $\mathrm{kgm}$. of cells and per $\mathrm{kgm}$. of water are appreciably increased.

The acid-base factors are presented in Table III.

After venesection in the normal male, the chlorides, phosphates, and proteinates are decreased somewhat, while the bicarbonate rises fractionally, and the total acid is reduced slightly. On the basic side, all factors are lowered and the total base is reduced significantly. The $\mathrm{pH}$ and $\mathrm{CO}_{2}$ capacity are practically unchanged.

Among the toxic patients, the changes are gen-

TABLE III

Acid-base equilibrium of the plasma before and after venesection

(Concentrations are reported in terms of milli-equivalents, $\mathrm{mEq}$., per kilogram of water)

\begin{tabular}{|c|c|c|c|c|c|c|c|c|c|c|c|c|}
\hline $\begin{array}{c}\text { Case } \\
\text { number }\end{array}$ & $(\mathrm{Cl})^{-}$ & $\left(\mathrm{HCO}_{3}\right)^{-}$ & $\begin{array}{c}\text { (Pro- } \\
\text { teinate)- }\end{array}$ & $\begin{array}{r}\left(\mathrm{HPO}_{1}\right)^{-} \\
+\left(\mathrm{H}_{2} \mathrm{PO}_{4}\right)^{-}\end{array}$ & $\begin{array}{l}\text { Total } \\
\text { acide T }\end{array}$ & $(\mathrm{Na})^{+}$ & $(\mathrm{Ca})^{++}$ & $(\mathbf{K})^{+}$ & $(\mathbf{M g})^{++}$ & $\begin{array}{l}\text { Total } \\
\text { base }\end{array}$ & $\mathrm{pH}$ & $\underset{\text { capacity }}{\mathrm{CO}_{2}}$ \\
\hline & $m E q$ & $m E q$. & $m E q$. & $m E q$. & $m E q$ & $m E_{q}$ & $m E q$. & $m E q$. & $m E q$. & $m E q$ & & $\begin{array}{l}\text { Volume } \\
\text { per cent }\end{array}$ \\
\hline $\begin{array}{r}94 a \\
b\end{array}$ & $\begin{array}{l}103.2 \\
102.9\end{array}$ & $\begin{array}{l}30.7 \\
31.4\end{array}$ & $\begin{array}{l}21.9 \\
20.6\end{array}$ & $\begin{array}{l}1.74 \\
1.70\end{array}$ & $\begin{array}{l}158.3 \\
157.4\end{array}$ & $\begin{array}{l}153.1 \\
145.5\end{array}$ & $\begin{array}{l}5.48 \\
4.97\end{array}$ & $\begin{array}{l}5.44 \\
5.37\end{array}$ & $\begin{array}{l}2.19 \\
2.18\end{array}$ & $\begin{array}{l}166.2 \\
158.0\end{array}$ & $\begin{array}{l}7.45 \\
7.48\end{array}$ & $\begin{array}{l}68.0 \\
68.9\end{array}$ \\
\hline $\begin{array}{r}89 a \\
b\end{array}$ & $\begin{array}{l}111.1 \\
109.9\end{array}$ & $\begin{array}{l}23.3 \\
20.9\end{array}$ & $\begin{array}{l}14.2 \\
13.4\end{array}$ & $\begin{array}{l}2.56 \\
2.44\end{array}$ & $\begin{array}{l}152.0 \\
152.0\end{array}$ & $\begin{array}{l}147.6 \\
144.9\end{array}$ & $\begin{array}{l}4.60 \\
4.45\end{array}$ & $\begin{array}{l}5.34 \\
5.52\end{array}$ & & $\begin{array}{l}159.7^{*} \\
157.1^{*}\end{array}$ & $\begin{array}{l}7.16 \\
7.25\end{array}$ & $\begin{array}{l}53.0 \\
50.1\end{array}$ \\
\hline $\begin{array}{r}90 a \\
b\end{array}$ & $\begin{array}{l}114.0 \\
113.3\end{array}$ & $\begin{array}{l}18.5 \\
17.0\end{array}$ & $\begin{array}{l}16.6 \\
17.9\end{array}$ & $\begin{array}{l}2.27 \\
2.21\end{array}$ & $\begin{array}{l}152.2 \\
151.2\end{array}$ & $\begin{array}{l}151.0 \\
149.1\end{array}$ & $\begin{array}{l}5.06 \\
5.17\end{array}$ & $\begin{array}{l}5.45 \\
5.67\end{array}$ & & $\begin{array}{l}163.7^{*} \\
162.1^{*}\end{array}$ & $\begin{array}{l}7.28 \\
7.41\end{array}$ & $\begin{array}{l}46.5 \\
45.8\end{array}$ \\
\hline $\begin{array}{r}91 \mathrm{a} \\
\mathrm{c}\end{array}$ & $\begin{array}{l}109.6 \\
108.8\end{array}$ & $\begin{array}{l}22.8 \\
23.8\end{array}$ & $\begin{array}{l}14.2 \\
14.9\end{array}$ & $\begin{array}{l}1.97 \\
1.86\end{array}$ & $\begin{array}{l}149.4 \\
150.2\end{array}$ & $\begin{array}{l}155.1 \\
148.6\end{array}$ & $\begin{array}{l}4.50 \\
4.27\end{array}$ & $\begin{array}{l}7.65 \\
6.27\end{array}$ & $\begin{array}{l}2.34 \\
2.28\end{array}$ & $\begin{array}{l}169.6 \\
161.4\end{array}$ & $\begin{array}{l}7.44 \\
7.62\end{array}$ & $\begin{array}{l}55.9 \\
56.5\end{array}$ \\
\hline $\begin{array}{r}92 a \\
b\end{array}$ & $\begin{array}{l}105.8 \\
104.0\end{array}$ & $\begin{array}{l}27.0 \\
25.8\end{array}$ & $\begin{array}{l}19.2 \\
19.0\end{array}$ & $\begin{array}{l}2.60 \\
2.63\end{array}$ & $\begin{array}{l}155.4 \\
152.2\end{array}$ & $\begin{array}{l}140.0 \\
141.9\end{array}$ & $\begin{array}{l}4.65 \\
4.65\end{array}$ & $\begin{array}{l}8.74 \\
9.12\end{array}$ & $\begin{array}{l}2.41 \\
2.18\end{array}$ & $\begin{array}{l}155.8 \\
157.9\end{array}$ & $\begin{array}{l}7.44 \\
7.50\end{array}$ & $\begin{array}{l}62.0 \\
59.0\end{array}$ \\
\hline $\begin{array}{c}93 a \\
b \| \\
c\end{array}$ & $\begin{array}{l}106.9 \\
108.1 \\
105.3\end{array}$ & $\begin{array}{l}23.6 \\
23.9 \\
23.6\end{array}$ & $\begin{array}{l}17.1 \\
17.1 \\
17.7\end{array}$ & $\begin{array}{l}2.22 \\
2.80\end{array}$ & $\begin{array}{l}149.8 \\
152.1 \ddagger \\
150.2\end{array}$ & $\begin{array}{l}153.8 \\
153.6 \\
146.1\end{array}$ & $\begin{array}{l}4.56 \\
4.80 \\
4.96\end{array}$ & $\begin{array}{l}5.64 \\
4.49\end{array}$ & $\begin{array}{l}2.32 \\
2.18 \\
2.28\end{array}$ & $\begin{array}{l}166.3 \\
166.2 \dagger \\
157.8\end{array}$ & $\begin{array}{l}7.38 \\
7.43 \\
7.41\end{array}$ & $\begin{array}{l}53.8 \\
55.5 \\
53.7\end{array}$ \\
\hline $\begin{array}{r}95 \mathbf{a} \\
\mathrm{b} \\
\mathrm{c}\end{array}$ & $\begin{array}{l}102.2 \\
103.0 \\
103.9\end{array}$ & $\begin{array}{l}26.6 \\
26.5 \\
27.0\end{array}$ & $\begin{array}{l}18.1 \\
17.7 \\
16.7\end{array}$ & $\begin{array}{l}3.89 \\
3.48\end{array}$ & $\begin{array}{l}151.6 \\
151.5 \\
151.98\end{array}$ & $\begin{array}{l}146.9 \\
141.6 \\
145.0\end{array}$ & $\begin{array}{l}5.16 \\
5.16 \\
5.16\end{array}$ & $\begin{array}{l}5.50 \\
5.50 \\
5.50\end{array}$ & $\begin{array}{l}2.57 \\
2.31\end{array}$ & $\begin{array}{l}160.1 \\
154.6 \\
157.9^{*}\end{array}$ & $\begin{array}{l}7.44 \\
7.48 \\
7.44\end{array}$ & $\begin{array}{l}59.6 \\
59.2 \\
61.5\end{array}$ \\
\hline
\end{tabular}

* Assumed the value of $\mathbf{2 . 2}$ for magnesium. $\dagger$ Assumed the value of 5.64 for potassium. $\ddagger$ Assumed the value of 2.2 for phosphates.
Assumed the value of $\mathbf{3 . 4 8}$ for phosphates.

If Assumed the same water data as in 93c. Assumed the value of 0.8 for sulfates. 
erally in the same direction and of approximately the same extent except that the hydrogen-ion concentration is invariably higher in the second specimen, and the variations are at times rather marked (0.13 in Case 90, and 0.18 in Case 91). This may be taken to indicate that the $\mathrm{pH}$ of the mobilized tissue fluid is considerably more alkaline than that of the blood stream, since the added increment of extravascular fluid represents only a small percentage of the total fluid in the vascular system, even after full equilibrium has been attained. From the evidence provided by the third samples (c) in Cases 93 and 95, it would appear that this increased alkalinity is of short duration.

\section{DISCUSSION}

There is a certain logic which suggests that one of the fundamental changes in toxic women may be a shift of the body generally toward the alkaline side. It has been known for years that, during recovery from a severe toxic episode, the urine is definitely alkaline for some days. In the second place, the hyperventilation of normal pregnant women (4), and especially of those suffering from the toxemia of late pregnancy (5), should lead to an acid deficit somewhere in the organism. Finally, the eclamptic convulsion, which so frequently interrupts the increasingly severe toxemias and is probably to be viewed as a "protective phenomenon," constitutes an ideal mechanism for combating an alkalosis. The severe generalized convulsions occurring in a condition of partial anoxemia due to the temporary cessation of respiration inevitably increase the acids in the body, as is illustrated by the sudden rise in the blood lactic acid.

The fact that the blood rarely shows a significant change in $\mathrm{pH}$ toward the alkaline side at any time during the toxemic manifestations has been viewed as opposing the concept of an alkalosis. The data here presented, however, serve to revive the idea that the excess base may be stored in the tissues, which generally participate in the physical changes accompanying the disease, and is then released into the blood as the tissue fluids enter the circulatory system to compensate for the blood loss. The increased $\mathrm{pH}$ of the second sample in each venesection was definitely determined by the method of procedure. In spite of the consistent elevation of the $\mathrm{pH}$, the $\mathrm{CO}_{2}$ capacity and the total acid and base constituents do not vary uniformly.

The explanation for these inconsistencies is not clear. It is apparent that the $\mathrm{pH}$ change in the male is the smallest in the series in spite of the fact that more blood was removed from him than from any of the toxemic patients. The total acid values do not include the organic acids, and it is conceivable that the toxemic individuals (even those without convulsions) have more of these substances in the blood, whereas the diluting tissue fluid is relatively deficient. Under such hypothetical conditions the blood would show a decreased total (including the organic) acid content at the end of the venesection. There is no available evidence to support such a contention, even though it would seem to offer the most logical explanation for the invariably increased blood alkalinity at the conclusion of the blood withdrawal.

The lack of uniformity in the behavior of the serum potassium during the blood letting is susceptible of a theoretic explanation. In three of the six toxemic women this constituent was slightly increased, in two it was definitely decreased, and in one there was no change; whereas in the male donor it was scarcely altered (a decrease of $0.07 \mathrm{mEq}$. per $\mathrm{kgm}$. of water). It is well known that ionic calcium lowers the permeability of a living membrane to potassium ions, and that the major portion of the base in tissue cells is potassium. The two patients who showed decreased serum potassium in the second blood sample were Number 91, a case of cardiovascular renal disease, and Number 93, a nonconvulsive toxemic. In the former, it is not unreasonable to postulate some deposit of calcium in the vessel walls or in the surrounding soft tissues, which reduced their permeability to potassium. In the second case, the serum calcium was considerably higher in the second blood sample. This finding suggests that the extracellular fluid calcium must have been elevated, and that a high tissue calcium might have induced a decreased permeability of the vessel wall and thus have interfered with the passage of the potassium ions into the blood stream. 


\section{CONCLUSIONS}

Venesection in women with various forms of the toxemia of late pregnancy induces blood dilution and an associated elevation of the blood $\mathrm{pH}$, which is not accounted for by determined changes in the concentrations of total acid and base.

\section{BIBLIOGRAPHY}

1. Oberst, F. W., and Plass, E. D., The acid-base balance and water concentration of the blood during the toxemias of late pregnancy (In press).
2. Oberst, F. W., and Plass, E. D., Water concentration of the blood during pregnancy, labor, and the puerperium. Am. J. Obst. and Gynec., 1936, 31, 61.

3. Oberst, F. W., and Plass, E. D., The acid-base balance in the plasma and blood cells of normal nonpregnant, pregnant, and puerperal women (In press).

4. Plass, E. D., and Oberst, F. W., Respiration and pulmonary ventilation in normal nonpregnant, pregnant, and puerperal women, with interpretation of acid base balance during normal pregnancy. Am. J. Obst. and Gynec., 1938, 35, 441.

5. Unpublished data. 